Pastor, Peter. "The American Reception and Settlement of Hungarian Refugees in 1956-1957." Hungarian Cultural Studies. e-Journal of the American Hungarian Educators Association, Volume 9 (2016): http://ahea.pitt.edu DOI:

\title{
The American Reception and Settlement of Hungarian Refugees in 1956-1957
}

\section{Peter Pastor}

\begin{abstract}
In the wake of the Hungarian Revolution of 1956, close to two hundred thousand Hungarians crossed into Austria. About thirty thousand of these refugees were allowed to enter the United States. Their common experience of living under totalitarian communism and participating or being a witness to the exhilarating thirteen days of the revolution and their sudden, previously unplanned, departure from the homeland gave them a collective identity that was different from the one shared by the people of previous waves of Hungarian influx to the United States. The high educational level of the refugees attained before and after their arrival made their absorption into the mainstream relatively easy. The integration process was facilitated by the shaping of a positive image of the 1956 refugees by the US government and the media. The reestablishment of the communist system in post-1956 Hungary contributed to the perception that, for the refugees in the United States, there was no hope for return to the homeland. This assumption strengthened the attitudes of those who wished to embrace the American melting pot model. Many of the 1956-ers in the United Sates, however, were also comfortable with the notion of ethnic pride and believed in the shaping of a dual national identity.
\end{abstract}

Keywords: Hungarian Revolution of 1956, United States response to the Hungarian Revolution of 1956, Hungarian refugees, President Dwight D. Eisenhower, the Soviet Union, Austria

Biography: Peter Pastor is Professor Emeritus of History at Montclair State University, New Jersey. His special interest is the history of diplomatic and military relations between Hungary and Russia/USSR. He is the author of numerous articles, a monograph, and editor or coeditor of several books, including the 2012 publication, Essays on World War I (with Graydon A. Tunstall).

For Hungary a major consequence of World War II was the Soviet occupation of the country in 1945, followed by the establishment of a communist dictatorship in 1948. Eight years later a revolution broke out in response to this oppression on October 23, 1956. Ten days later the uprising was crushed by the overwhelming power of the Soviet army and the Hungarian communists were restored to lead the party-state. In the wake of defeat, 200,000 Hungarians escaped to neighboring Austria and about 38,000 found haven in the United Sates. The absorption of the refugees through a well-organized governmental program proved to be speedy and successful. Most of the Hungarians adjusted to their new life in America without much difficulty, and while some retained a dual identity in the direction of multiculturalism, others lost their ties to the old country and became successfully acculturated to their host society. 
Pastor, Peter. "The American Reception and Settlement of Hungarian Refugees in 1956-1957." Hungarian Cultural Studies. e-Journal of the American Hungarian Educators Association, Volume 9 (2016): http://ahea.pitt.edu DOI:

The Hungarian revolution of 1956 was named the "Unexpected Revolution" by one of its early historians, Paul Kecskeméti. The anti-communist and patriotic uprising started with peaceful demonstrations by university students and their sympathizers on October 23, 1956. They called for reforms, the end of the communist dictatorship, independence, and the withdrawal of Soviet troops from Hungary. The protest turned into a full-fledged revolution as a result of the ill-considered response of the authorities, which ordered the internal security forces and Soviet troops stationed in Hungary to use firepower against the crowds. Violence was met with resistance and according to official statistics, on October 23 and 24, more than 250 died in the clashes. In the insurgence that continued, Charles Gati in his Failed Illusions estimates that "In a country of less than ten million, those who took up arms...numbered no more than 15,000 [although practically all Hungarians stood shoulder to shoulder with them]" ( Gati 2006: 3, Litván 1991: 88). National councils and workers councils were spontaneously formed representing the Hungarians who turned against the system. The situation was called a counterrevolution by TASS, the official Soviet news agency and fresh Soviet reinforcements were dispatched starting on October 24, although they were not ordered to intervene. Apparently, the Party's Presidium in Moscow, also taken aback by the Hungarian development, was considering various scenarios for action.

In some towns outside of Budapest unarmed demonstrators were also met by fusillades with scores of dead. On October 26, in the hope of ending the spread of the violence, the Central Committee of the Communist Party called for the formation of a new coalition government headed by the reform communist Imre Nagy. The revolution seemed to achieve victory when on October 30, Prime Minister Imre Nagy announced on radio the end of the one party-system and the formation of a democratic coalition government. The next day, responding to news of a Hungarian multi-party system, the Soviet Party's Presidium, led by Nikita S. Khrushchev, decided to intervene and crush the revolution and ordered the invasion of by now peaceful Hungary by fresh Soviet forces. The Soviet attack under the code name "whirlwind" commenced on November 4, 1956, with 60,000 troops, and 2,000 tanks crushed the resistance in Budapest by November 10-11 (Eörsi 2006: 22). The leaders of the revolution were arrested and later executed. The human cost of the revolution in Budapest was close to 20,000 wounded, about 2,500 dead, fifty percent of them under thirty (Horváth 2003: 441, Litván 1991: 89). From among the Hungarian internal security forces 279 were killed in the conflict, and 669 Soviet soldiers died and more than 1,500 were wounded (Horváth 2003: 441, 443). Once the old order was restored, the repressions started. The courts handed down 22,000 prison sentences of various length and about 300 were executed for participation in the revolution.

The specter of the return of the communist dictatorship, renewed Soviet colonialism, and repression forced about 200,000 Hungarians to escape from Hungary in November and December 1956 while the borders had not yet been secured by the reconstituted border police. Some escaped to Yugoslavia, but most to Austria. While until 1955 a barbed wire "iron curtain" on the Austrian border kept the Hungarians from escaping, after the signing of the Austrian State Treaty that ended the four-power occupation of Austria, in the spirit of "peaceful coexistence," the fence was eliminated, and the mines on the Hungarian side of the border were picked up, making the crossing to Austria even more inviting. For this reason refugees, who saw the breakdown of order as a chance at last to go to the West, started to trickle in by the hundreds as early as October 28, before the revolution was crushed. Most of these escapees were peasants from villages close to the border (Bursten 1958: 38, 40), but with the November exodus the 
Pastor, Peter. "The American Reception and Settlement of Hungarian Refugees in 1956-1957." Hungarian Cultural Studies. e-Journal of the American Hungarian Educators Association, Volume 9 (2016): http://ahea.pitt.edu DOI: 10.5195/ahea.2016.255

social make-up and origin of the refugees changed radically. Most, seventy-two percent, came from urban areas, with fifty-three percent from Budapest, and only twenty-eight percent from rural communities (Központi Statisztikai Hivatal 1991: 191). This distribution in favor of urban refugees explains why most who arrived in the United States settled in major urban areas, with the largest number in New York and Cleveland (Puskás 2000: 276).

Responsibility for solving the huge refugee problem that developed in Austria in November 1956 fell on the shoulders of the Western democracies, including the United States. Until the arrival of the refugees in Austria, the US was a distant, hands-off observer of the unfolding events in Hungary. Even though the Cold War policy shaped by Secretary of State John Foster Dulles was predicated on the rollback of communism and the liberation of the socalled captive nations, the outbreak of the Hungarian Revolution caught the US off-guard. Short of starting a major war with the Soviet Union, it became evident that the liberation policy was a failure. As President Eisenhower later conceded, for the US Hungary was "as inaccessible as Tibet." In a way, standing up for the refugees was a foreign relations coup and ameliorated the declining prestige of the US for "letting the Hungarians down" (Bursten 1958: 53). As early as November 2, the White house announced humanitarian aid to the refugees in Austria and to the people in Hungary (Markowitz 1973: 46-47).

Early in November the Suez Canal crisis in the Middle East was on the front burner and Washington's major concern was to keep the Russians out of Egypt. On November 8, 1956, two days after his massive reelection victory, President Eisenhower noted in his diary that real peace in the area would be achieved only if governments are impressed upon to "exclude communist influence" and the way to do this was to provide "all the details and implications of the Soviet suppression of the Hungarian revolt. We should, I think, get all the proof that there is available, including moving pictures taken of the slaughter in Budapest. We must make sure that every weak country understands what can be in store for it once it falls under the domination of the Soviets" (Ferrel 1981: 334). One of the "details" of the suppression that were to be used were the refugees and in a CIA review about the revolution and its aftermath, it was noted that "On 6 November we were already talking about the mechanics and methods of exploiting the refugees" (Gati 2006: 203).

While for the governmental leaders a positive response toward the refugee question was politically desirable, to the American people the decision makers' policy was a welcome humanitarian gesture. In the US the uprising was the first such event that was televised from its outbreak to its end and it left a deep impression on the mind of millions of viewers, generating an outpouring of enormous sympathy, which was reflected in the media. Thus the January 7, 1957, issue of Time magazine named the "Hungarian Freedom Fighter" the man of the year (Time 1957: 18-22).

On the Hungarian side, the media image of the refugee as a freedom fighter was also imprecise. The two leading historians of Hungarian emigration, Steven Béla Várdy and Julianna Puskás, estimate that only some five percent of the refugees took up arms during the short-lived revolution and hence saw the need to escape to avoid persecution, while the rest left because they feared the return of the pre-1956 totalitarian system (Várdy 2000: 448, Puskás 2000: 274-275). An Austrian survey taken by experts in two refugee camps between November 22 and 26 reinforce Várdy's and Puskás's claim, since those who were questioned identified fear as the major reason for their departure from Hungary. Interestingly, forty-seven percent wanted to leave Austria as soon as possible and forty-three percent wanted to go to the US (Glant 26: 157-158). 
Pastor, Peter. "The American Reception and Settlement of Hungarian Refugees in 1956-1957." Hungarian Cultural Studies. e-Journal of the American Hungarian Educators Association, Volume 9 (2016): http://ahea.pitt.edu DOI: 10.5195/ahea.2016.255

The major reason cited by the surveyed Hungarians for having escaped from Hungary is not too far from the (June) 1958 finding of the Zellerbach Commission on European Refugees, a private American group, which in its report concluded that the "refugees from all Communist countries...have fled in short, from the actuality of everyday oppression rather than from the fear of personal persecution" (Gatrell 2011: 54). The resettlement process that within three months brought 30,000 of the refugees to the American shores, represented a novel approach to immigration policy, as instead of the legislative branch, it was the White House that took charge of the effort (Bon Tempo 2008: 66). The program started with the November 8, 1956 announcement that 5,000 so-called escapee visas would be made available for the Hungarian refugees from the Refugee Relief Act of 1953, which was about the expire at the end of December. At the time of the official termination of the Emergency Program for Hungarian Refugees on December 8, 1957, it was stated that 6,130 of the 38,000 refugees who found haven in the US were admitted with escapee visas. The rest entered under Section 212 (d) (5), known as the parolee provision of the Immigration and Nationality Act [The McCarran-Walter Act] (Markowitz 1973: 47-48, National Archives 1999: 851, Bursten 1958: 54). The parole allowed the holder to live and work in the US, but did not make him/her a resident. The Hungarian parolees were given formal immigrant status only in July 1958, through legislative action (Markowitz 1973: 57) when it was clear that they would not return to Hungary soon.

The secretary of defense was charged with working out the transport of the refugees to the US and their reception. About 9,000 of the refugees were transported via four WW II troop carriers; one of them making a second trip, the rest came by air transport [Flying Tigers] (Bursten 1958: 183). For the reception of Hungarian refugees in the US the mothballed US Army reception center in New Jersey, Camp Kilmer, was reopened under the Command of Brigadier General Sidney C. Wooten. He welcomed the first sixty refugees on November 21, when they deplaned at nearby McGuire Air Force Base (Markowitz 1973: 48, Bon Tempo 2008: 68). On November 26 at a well-publicized reception, President Eisenhower welcomed some Hungarian refugees to the White House (Ambrose 1984 2: 376). Two days later, the president appointed Tracy S. Voorhees as his personal representative to the Joyce Kilmer Reception Center and when the President's Committee for Hungarian Refugee Relief, consisting of fourteen prominent Americans, was set up on December 12, Voorhees became its chairman. His committee's goal was to coordinate contact between the twenty-two governmental and voluntary agencies helping the refugees (ArchiveGrid 1957).

The major objective of the activities related to the speedy resettlement of the refugees through finding them homes and employment (U.S. President's Committee for Hungarian Refugee Relief 1957, Bursten 1958: 163), and the effort to integrate the refugees with governmental and non-governmental organs, proved to be extremely successful (Bursten 1958: 166). Departing from governmental "standard operating procedure," Voorhees, using privately collected funds, hired a Madison Avenue public relations firm to put the government program into media focus, thus facilitating the speed of finding housing and jobs for the refugees (Bursten 1958: 163). The projected image showed the Hungarians as victims of Communism and stressed that they also had all the qualities of becoming good Americans (Bon Tempo 2008: 75).

The March 24, 1957 New York Times article by the Pulitzer Prize winner for international reporting in 1955, Harrison E. Salisbury, is an example of the success of Voorhees's effort to present the refugees in a positive light. The report, starting on the paper's first page, was entitled "Hungarian Refugees Blend Easily Into U.S. Way of Life." Here, 
Pastor, Peter. "The American Reception and Settlement of Hungarian Refugees in 1956-1957." Hungarian Cultural Studies. e-Journal of the American Hungarian Educators Association, Volume 9 (2016): http://ahea.pitt.edu DOI: 10.5195/ahea.2016.255

Salisbury noted that "in the realistic appraisal of top social workers there has never been a more successful mass migration in American history." The article boasted the headline "Most Hungarian Refugees Are Making a Quick Adjustment to Life in the U.S." on a second page. Here the author noted that "Dispersion of the refugees follows the general population pattern of the United States, with bulges for existing centers of Hungarian settlement." Salisbury attributed swift adjustment to the "youthful composition of the refugee group... an abundance of useful work skills and a lack of deterioration from years in refugee camps." His last observation was a clear reference to DPs, who had to wait for years in refugee camps to be admitted to the United States. The Hungarian DPs already in the US, roughly 26,377 (Várdy 2000: 447, Puskás 2000: 264) indeed had less "work skills" than the "56-ers. For example, when it came to professional and managerial skills 18.1 percent of the refugees belonged to this category against 3.6 percent of DPs. The skilled workers among the refugees comprised 32.2 percent of the total against 11.5 percent of the DPs (Bursten 1958: 183).

The positive aspect of the "youthful composition" of the 1956 group was also noted by Fred Schoenborn, who headed the seventy-five-member staff of the US Department of Labor who interviewed the refugees for job placement. In an interview in the summer of 1957 he stressed that 72.5 percent were between the ages of 16 and 45 , and 40 percent were single, primarily males. He commented that the "youthful average age assures us of a significant number of productive workers for many years ahead." He also claimed that the refugees "readily acclimate themselves to our country" (Bursten 1958: 184). The "useful work skills" mentioned by Salisbury also contributed to the integration of the refugees. S. Alexander Weinstock, who studied Hungarian immigrants to the United States, noted the successful integration of the '56ers. He concluded: "With reference to industrialized societies, the higher the immigrant's position on the occupational prestige scale in the country of origin, and the greater the transferability of his skill, the more acculturated he is likely to become in the country where he settles" (Weinstock, 1963: 148, Weinstock, 1969: 105).

The useful work skills of the refugees was also accentuated by Labor Secretary James P. Mitchell in his article, "Freedom's \$30 Million Bonus" which appeared on May 10, 1957, in the New York Herald Tribune on the occasion of the closing of Camp Kilmer. In the article he presented favorable statistics as he wrote, "Finally the most important, the largest occupational group - 34 percent - have skills currently needed in American industry while the next largest group - some 18 percent - are engineers, doctors and other professional people very much in demand in our country. The National Academy of Sciences estimates that the education of these Hungarian scientists, engineers and other university graduates represents an investment of over $\$ 30$ million" (Mitchell 1957, Bursten 1958: 182). The skill sets of the refugees were also recognized by President Eisenhower, who on December 25, 1956, following the return of Vice President Richard Nixon from a fact-finding trip to Austria, declared that the issuance of visas should be accelerated, otherwise "the pick of the refugees will go to other countries" (Ambrose 1984 2: 377).

While in the words of Mitchell the refugees represented an "economic bonus" for the US, it signified a brain drain and a demographic tsunami for Hungary. The 200,000 refugees corresponded to the annual birth rate in the late fifties and the natural population increase for four years. The Hungarian government tried to encourage the return of the refugees by offering them amnesty (Puskás 2000: 273-274), but only about 147 decided to return to Hungary from the US (Bursten 1958: 196). A commentator noted that of the total of " 11,600 refugees who 
Pastor, Peter. "The American Reception and Settlement of Hungarian Refugees in 1956-1957." Hungarian Cultural Studies. e-Journal of the American Hungarian Educators Association, Volume 9 (2016): http://ahea.pitt.edu DOI: 10.5195/ahea.2016.255

returned, 8,000 had never got further than Vienna" (Sterling 1958: 24). The failure to entice the '56-er refugees to return home and thereby also strengthen the legitimacy of the communist government was admitted by a 1961 Politburo decision of the Hungarian communist party when it stated that "the majority of the 1956 and 1957 defectors settles permanently abroad and degree by degree takes on the characteristics of certain strata of the old emigration" (Szabó 2007: 212). In 1964 a committee in the Ministry of Foreign Affairs concluded that since the majority of the refugees would not return and had already become integrated into the society of the host country, they would become significant shapers of the host country's opinion about Hungary and would be important factors in bilateral relations, and that therefore winning them over was an important long-run task (Szabó 2007: 213).

The effortless ability to integrate into American society was emphasized by Salisbury's article mentioned earlier. He introduced the reader to various refugees who already made the transition. Among these was Mrs. Ildikó Rath, a "23-Year-Old Heroine [Who] Has Become a Model Housewife." According to the caption under her photo, she "arrived at Camp Kilmer last November, bearing wounds of the uprising in Budapest. She had killed five Russians. Today she and her husband, Karl, a newspaper photographer in Harrisburg, Pa. have many friends and are leading figures in their community's activities." Clearly the caption here revealed victimhood, being shot by the Russians, and the positively perceived aspect of American life during the midfifties: being a housewife and being engaged in community activities. Of the others about whom Salisbury reported on in the article, the story of the Petrus brothers also stand out. "If you asked George Petrus 20 and Frank 24, how they are getting on in America they would tell you they didn't have a problem in the world. Except, possibly one. 'American girls... are colder than Hungarian girls."”

The article states that George's English lacked a few grammatical refinements, but that he makes himself understood. It continues to say that the brothers worked at a factory in Bloomfield, N.J.; George earned \$1.60 an hour on a forty-hour week, Frank made \$1.50 an hour on a fifty-hour week. As to education, George hoped to study electronics in a University, while Frank wanted to study high-voltage electrical techniques. The article continues to say that: "Frank says that they are going to buy a car in June when they have saved a little money. Once they have a car they hope to make further study of the relative 'temperature' of Hungarian and American girls" (Salisbury 1957: 1). Romance during the fifties was clearly tied to the automobile where the back seat provided room for the amorous encounters of young American couples.

While doing research for this paper, discovering the Petrus brothers in the New York Times was an unexpected surprise, as during the past ten years I had the pleasure to meet Frank and his wife at the monthly dinner-dance that I attend with my wife at the Garfield American Hungarian Citizens League clubhouse. During the last dinner last month, on May 31, I showed him Salisbury's 1957 article and he learned almost sixty years after the fact that he and his brother had made the New York Times. For me what was significant is that I had a complete picture how the "blending into American life," mentioned by Salisbury, turned out for the brothers. I learned from Frank that soon in 1957 George was accepted to the Newark College of Engineering (which in 1973 became New Jersey Institute of Technology). He married twice, both times to "American girls," and from the first marriage he has two adult children. His second wife is fourteen years younger. According to Frank, unlike himself, his brother George, who became very wealthy by wise investment in real estate, has no contact with Hungarians. 
Pastor, Peter. "The American Reception and Settlement of Hungarian Refugees in 1956-1957." Hungarian Cultural Studies. e-Journal of the American Hungarian Educators Association, Volume 9 (2016): http://ahea.pitt.edu DOI: 10.5195/ahea.2016.255

Frank, now eighty-four, married a "Hungarian girl," who was also a refugee and arrived in New York after May 10, 1957, when Camp Kilmer closed; four days later Eisenhower dissolved the President's Committee for Hungarian Refugee Relief (New York Post 1957). After that the trickle of Hungarian refugees from Austria were briefly housed in Brooklyn's St. George Hotel before they were picked up by relatives or sponsors. Frank and Magda had four sons, the youngest, Stephen, is an American historian whose dissertation was on Greenwich Village. Frank is semi-retired and still works in his machine shop that he established during the late sixties in Parsippany, NJ. He owns the building and the property around it. Frank is active in the leadership of the Garfield club which was established in 1953 by some Hungarian immigrants, but which began to flourish with the arrival of the '56-er refugees (Mattyasovszky and Papp 2013: 8-10). The life story of the Petrus brothers is a good illustration of the different roads the '56-ers took. One brother, George, assimilated. His life in America demonstrates the working of the "melting pot" principle. Frank, on the other hand is a model for multiculturalism, for the "new ethnicity." He integrated into American society without giving up his Hungarian ethnic ties. Both brothers, however, could be identified as successful Americans.

Two other very successful '56-ers, although not brothers, demonstrate the same kind of bifurcation of identities. Both arrived to the United States as college-age males. When the revolution broke out, one already started his university studies in Hungary, the other was doing his required military service in a labor battalion. The latter, László Bitó, from Camp Kilmer went to Cleveland, where he learned about the Bard College program financed by the Ford Foundation. The nine-week intensive English course, just as the ones at other colleges, was designed to help integrate the Hungarian refugee students into American college life. Estimates of college student refugees who wanted to continue their studies was between 1,000 to 1,726 (Gousha 2011: 50). Following the Bard program in the winter of 1956-1957, Bitó received one of the two Bard College scholarships. Graduating in 1960, he earned his Ph.D. in Biophysics in 1963 and after two years of postdoctoral training he was invited to join the Columbia faculty from which he retired in 1997 as Professor Emeritus of Ocular Physiology. At Columbia he devised a new approach to the medical management of glaucoma and developed a new drug to treat the illness, Xalatan. Bitó continued to keep in touch with Hungarian issues and he became wealthy from his discovery. He eventually financed the teaching of Hungarian literature in English at Columbia and provided substantial financial support to the Deák Chair which emphasizes Hungarian Studies at the Center for East Central Europe. In his retirement he spends most of his time in Hungary where he became a recognized novelist writing in Hungarian. The career of Bitó indicates that he constructed a multicultural, or dual ethnic identity for himself in which becoming an American did not exclude his retention of his Hungarian identity. His second wife, Olivia Corino, with whom he lives in Budapest, is of Filipino origin.

The other 1956 refugee college student started his studies in chemical engineering at City College of New York in the spring of 1957. András Gróf received a World University Service scholarship for his first semester and the following semester a part-time job in the Chemical Engineering Department. When he graduated in 1960 the New York Times reported his success in a news article: "A Hungarian Refugee who three years ago didn't know horizontal from vertical - in English — will be graduated from City College today at the head of the class of engineering students" (New York Times 1960: 22). By then the freshly minted graduate had Americanized his name to Andrew S. Grove. Grove later became the CEO of Intel, and in 1997 he became Time magazine's "Man of the Year" (Tedlow 2006: xxi). In 1957 soon after his 
Pastor, Peter. "The American Reception and Settlement of Hungarian Refugees in 1956-1957." Hungarian Cultural Studies. e-Journal of the American Hungarian Educators Association, Volume 9 (2016): http://ahea.pitt.edu DOI: 10.5195/ahea.2016.255

arrival to New York, Andy Grove severed his ties to Hungary and he never returned to the country of his birth. In 1958 he married a non-Hungarian, Eva Kastan, who was born in 1935 in Vienna and escaped with her parents the Nazi pogrom there when she was three. She grew up in Bolivia before she emigrated to the US (Tedlow 2006: xiii, 69). Grove reflected on these decisions in his memoirs: "My life started over in the United States. I have set roots here. Whatever roots I had in Hungary were cut off when I left and have since withered and died. Meanwhile, my life here has flourished" (Grove 2001: 287).

The diverse examples mentioned here reinforce a conclusion that had been offered by observers of "56-er emigration. The youthful character of the refugees as a group facilitated integration and so did, as a 1967 study on refugee adjustment in New York City noted, the "relatively high level of education, skill and facility with language" (Soskis 1967: 46). Susan Papp, an historian of Hungarian Americans in Cleveland, saw similar development in that city. She noted that "the newcomers adjusted with greater ease than the previous waves due to their youth and the many opportunities that were offered," and "as a direct result of their relatively rapid adjustment, the newcomers exhibited less attachment to [Hungarian] community organizations and institutions" (Papp 1990: 276-277). The convergence of these factors indicate that out of defeat in Hungary the refugees created success stories in the United States that conform to the model of America as both the melting pot and the multicultural world for the immigrants.

\section{Works Cited}

Ambrose, Steven. 1984. Eisenhower. Vol. 2. The President. New York: Simon and Shuster. ArchiveGrid. 1957. "The President's Committee for Hungarian Refugee Relief Papers." http://184.168.105/archivegrid/collection/data/63761634. Accessed 06/01/2014.

Bon Tempo, Carl J. 2008. Americans at the Gate: The United States and Refugees During the Cold War. Princeton: Princeton University Press.

Bursten. Martin A. 1958. Escape from Fear. Syracuse: Syracuse University Press.

Eörsi, László. 2006. The Hungarian Revolution of 1956: Myths and Realities. Boulder, CO: East European Monographs.

Ferrel, Robert H., ed. 1981. The Eisenhower Diaries. New York: Norton.

Gatrell, Peter. 2011. Free World? Campaign to Save the World's Refugees, 1956-1963. New York: Cambridge University Press.

Gati, Charles. 2006. Failed Illusions. Washington, DC: Woodrow Wilson Center Press.

Glant, Tibor. 2006. Remember Hungary 1956: Essays on the Hungarian Revolution and War of Independence in American Memory. Boulder, CO: East European Monographs.

Gousha, Laura. 2011. “'Extraordinary Measures”: The Funding of Hungarian Refugee Students by the Rockefeller Foundations, 1956-1958." MA Thesis. Budapest: Central European University.

Grove, Andrew S. 2001. Swimming Across (A Memoir). New York: Warner Books.

Hidas, Peter. 1998. "The Hungarian Refugee Student Movement of 1956-1957 and Canada." Canadian Ethnic Studies. 30. 1: 19-49.

Horváth, Miklós. 2003. 1956 hadikrónikája ['The Military Chronicle of 1956’]. Budapest: Akadémiai Kiadó. 
Pastor, Peter. "The American Reception and Settlement of Hungarian Refugees in 1956-1957." Hungarian Cultural Studies. e-Journal of the American Hungarian Educators Association, Volume 9 (2016): http://ahea.pitt.edu DOI: 10.5195/ahea.2016.255

Központi Statisztikai Hivatal. 1991. "KSH jelentés az 1956-os disszidálásról. Az illegálisan külföldre távozott személyek főbb adatai (1956. október 23-1957. április 30.)” ['KSH Report on the 1956-er Defection: The Major Data of People Who Illegally Departed to Abroad (October 23, 1956-April 30, 1957)']. Regio-Kisebbségi Szemle 2/4: 174-211.

Litván, György ed. 1991. Az 1956-os magyar forradalom. Reform. Felkelés. Szabadságharc. Megtorlás ['The 1956 Hungarian Revolution: Reform, Uprising, Reprisal']. Budapest: Tankönyvkiadó.

Markowitz, Arthur A. 1973. "Humanitarianism versus Restrictionism: The United States and the Hungarian Refugees." International Migration Review. 7/1: 46-59.

Mattyasovszky, György and Imre Papp. 2013. 1953-2013: American-Hungarian Citizens League Garfield N.J. Little Ferry, NJ: Martin Printing Shop.

Mitchell, James P. 1957. “Freedom’s \$30 Million Bonus.” New York Herald Tribune, May 10. National Archives. 1999. "Public Papers of the Presidents of the United States, Dwight D. Eisenhower, 1957: Containing the Public Messages, Speeches, and Statements of the President, January 1 to December 31, 1957." Washington, DC: US Printing Office.

New York Post. 1957. “Camp Kilmer Closed, Last Refugees Leave.” May 10.

New York Times. 1957. President Ends Refugee Panel But Pledges More Aid." May 15.

—. 1960. "Refugee Heading Engineers' Class." June 15.

Papp, Susan M. 1990. Hungarian Americans and Their Communities of Cleveland. Cleveland, $\mathrm{OH}:$ Cleveland State University.

Puskás, Julianna. 2000. Ties that Bind, Ties that Divide: 100 Years of Hungarian Experience in the United States. New York: Holmes and Meier.

Salisbury, Harrison E. 1957. "Hungarian Refugees Blend Easily Into U.S. Way of Life." New York Times. March 24.

Soskis, Philip. 1967. "The Adjustment of Hungarian Refugees in New York." International Migration Review. 2/1: 40-46.

Sterling, Claire. 1958. "What Happened to the Hungarian Refugees." The Reporter. October 30.

U.S. President's Committee for Hungarian Refugee Relief. 1957. Records. Arlene, Kansas: Dwight D. Eisenhower Library.

Szabó, Juliet. 2007. ““...s várja eltévedt fiait is.’ Az MSZMP repatriálási és hazalátogatási] politikája 1956 és 1963 között” [“...And Waits for Its Lost Sons Too.' The Hungarian Socialist Workers Party Policy on Repatriation and Home Visit']. Múltunk 52/1 : 187213.

Tedlow, Richard S. 2006. Andy Grove: Life and Times of an American. New York: Portfolio. Time. "Man of the Year." 1957. 69/1: 18-22.

Várdy Béla. 2000. Magyarok az Újvilágban ['Hungarians in the New World']. Budapest: Anyanyelvi Konferencia.

Weinstock, S. Alexander. 1969. Acculturation and Occupation: A Study of the 1956 Hungarian Refugees in the United States. The Hague: Martinus Nijhoff.

. 1963. "Role Elements: A Link between Acculturation and Occupational Status." The British Journal of Sociology. 14/2: 144-149. 